\title{
NOTES
}

\section{"FOLLOW-THE-LEADERS" CLAUSES: THE USE OF ANCILLARY COVENANTS AS A VEHICLE FOR COOPERATIVE OLIGOPOLY*}

Section 1 of the Sherman Act condemns all contracts, combinations and conspiracies whose purpose or effect is unreasonably to restrain competition. ${ }^{1}$ Selling or licensing agreements entered into in the ordinary course of business may contain ancillary provisions which restrain competition in the market." Such provisions restrain trade unreasonably unless they are essential to protect the contracting parties, and do not interfere substantially with the in-

*United Artists Corp. v. Strand Productions, Inc, 216 F.2d 305 (9th Cir. 1954).

1. "Every contract, combination in the form of trust or otherwise, or conspiracy, in restraint of trade or commerce among the several states . . . is hereby declared to be iilegal." 26 STat. 209 (1890), 15 U.S.C. \& 1 (1952). Certain agreements, such as price fixing, market sharing, boycotting, are unreasonable per se. See, c.g., United States v. Socony Vacuum Oil Co., 310 U.S. 150 (1940); Addyston Pipe \& Steel Co. v. United States, 175 U.S. 211 (1899); Fashion Originators' Guild v. FTC, 312 U.S. 457 (1941). As to other forms of agreements in restraint of trade, however, the "rule of reason" calls for a broader investigation of market effects, for "the legality of an agreement or regulation cannot be determined by so simple a test, as whether it restrains competition. Every agreement concerning trade, every regulation of trade, restrains. To bind, to restrain, is of their very essence. The true test of legality is whether the restraint imposed is such as merely regulates and perhaps thereby promotes competition or whether it is such as may suppress or even destroy competition. To determine that question the court must ordinarily consider the facts peculiar to the business to which the restraint is applied; its condition before and after the restraint was imposed; the nature of the restraint and its effect, actual or probable." Board of Trade of Chicago v. United States, 246 U.S. 231, 238 (1918) ; see United States v. American Tobacco Co., 221 U.S. 106, 178-80 (1911); Standard Oil Co. v. United States, 221 U.S. 1, 59-64 (1911).

2. The parties to a selling agreement may not be in competition, but the ancillary provisions may affect the relations of either party with his competitors by denying a fair opportunity to compete to persons not parties to the contract. See 6 Condu, Cositusers $\S 1412$ (1951). Thus "tying" arrangements which deny the seller's competitors access to a substantial number of buyers have been condemned under $\S 1$. International Salt $C o . v$. United States, 332 U.S. 392 (1947) ; United States v. General Motors Corp., 121 F.2d 376 (7th Cir.), cert. denied, 314 U.S. 61 (1941); United States v. American Can Co., 87 F. Supp. Is (N.D. Cal. 1949). Exclusive dealing contracts may be illegal for the same reasun. United States v. Richfield Oil Corp., 99 F. Supp. 280 (S.D. Cal. 1951), aff'd fer curiam, 343 U.S. 922 (1952) ; Continental Wall Paper Co. v. Louis Voight \& Sons Co., 212 U.S. 227 (1909).

Provisions whereby a licensor fixes the prices at which multiple licensees may sell a patented product are illegal per se because they restrict price competition between licensees. United States v. Paramount Pictures, Inc., 334 U.S. 131, 143-44 (1948). Recent Supreme Court cases indicate that a patent or copyright affords the licensor little or no protection from the antitrust laws. Compare United States v. General Elec. Co., 272 U.S. 476 (1926), 
terests of the public in free competition. ${ }^{3}$ Thus, ancillary provisions may be unreasonable because they promote the formation or execution of an illegal conspiracy. ${ }^{4}$ But they may also be unreasonable because of their direct effect upon competition; 5 if they are, they are unenforceable as against public policy." However, courts and attorneys have tended to search for conspiracies rather than to focus upon the restraining effects of ancillary clauses.

In the recent case of United Artists Corp. $v$. Strand Productions, Inc., ${ }^{8}$ the ninth circuit summarily dismissed the competitive significance of an ancillary provision contained in identical film distribution contracts. In 1949 United Artists, a major film distributor, was licensed as the exclusive distributor of four feature films made by James Nasser, an independent producer. ${ }^{0}$ The

zeith United States v. Paramount Pictures, Inc., supro at 144; United States v. Line Material Co., 333 U.S. 287, 299-305, 310-12 (1948) ; United States v. United States Gypsum Co., 333 U.S. 364, 389-91, 400-02 (1948) ; United States v. Masonite Corp., 316 U.S. 265, 280, 282 (1941); Ethyl Gasoline Corp. v. United States, 309 U.S. 436, 457-58 (1940). See 6 Corbin, Contracts $\$ 1410$ (1951).

3. A restraint is "unreasonable" in the sense that it is illegal, hence unenforceable, if it is greater in duration or in scope than is necessary to protect the person for whose benefit it is imposed; or imposes an undue hardship upon the person restricted; or tends to create a monopoly or limit artificially production or control prices; or unreasonably restricts the alienation or use of property or property rights. Restateunnt, Contracts $\S 515$ (1932) ; United States v. Addyston Pipe \& Steel Co., 85 Fed. 271, 281 (6th Cir. 1898). See also, e.g., United States v. Paramount Pictures, Inc., 334 U.S. 131, 144-48 (1948) ; Chorak v. RKO Radio Pictures, Inc., 196 F.2d 225 (9th Cir.), cert. demicd, 344 U.S. 887 (1952) ; United States v. Bausch \& Lomb Optical Co., 45 F. Supp. 387, 398-99, aff'd, 321 U.S. 707 (1944); Dr. Miles Medical Co. v. Park \& Sons Co., 220 U.S. 373 (1911).

4. United States v. Bausch \& Lomb Optical Co., 321 U.S. 707, 724 (1944); United States v. Univis Lens Co., 316 U.S. 241, 254 (1941); Ethyl Gasoline Corp. v. United States, 309 U.S. 436, 461 (1939).

5. See notes 2 and 3 supra.

6. "Ever since 1415 the common law courts had been refusing to enforce contracts or agreements 'in restraint of trade' or tending toward a monopoly. ..." Lockhart, Violation of the Anti-trust Laws as a Defense in Civil Actions, 31 Minn. L. Rev. 507, 512 (1947). Restatement, Contracts $\$ 514$ (1932); 6 Corbin, Contracts $\$ \S 1375,1402$ (1951). Sce Apex Hosiery Co. v. Leader, 310 U.S. 469, 497 (1940) (dictum).

The Supreme Court has been reluctant to permit one party to a contract of sale to renounce his obligations on the grounds that the contract was unenforceable becausc "collateral to" a conspiracy of which the other party was a member. See note 24 infra; Lockhart, sutpra, at 516-540. Apparently this has discouraged the use of antitrust defenses in civil suits even when the contract's direct, rather than collateral, effect is to restrain competition.

7. Thus, attorneys and courts have tried to find "intra-corporate conspiracies" in cases where, conspiracy or not, the parties were using contracts the effect of which was to restrain competition. See, e.g., Kiefer-Stewart Co. v. Joseph E. Seagram \& Sons, Inc., 340 U.S. 211 (1951) ; United States v. General Motors Corp., 121 F.2d 376 (7th Cir.), ccrt. denied, 314 U.S. 618 (1941); Comment, 63 YALE L.J. 372 (1954).

8. 216 F.2d 305 (9th Cir. 1954).

9. Id. at 307 . A licensing agreement is the standard method by which a motion picture 
future effect of television on the movie industry was then uncertain. ${ }^{10}$ United therefore covenanted that, if television should become a "commercial practice," it would distribute the films to television "in the same manner . . . as may be from time to time adopted" by other major distributors. ${ }^{11}$ However, neither United nor any other major has ever distributed feature films to television. ${ }^{12}$ Strand and Ressan, Nasser's successors in interest, brought suit to recover the television rights. ${ }^{13}$ They contended that it was sound and profitable business policy for United to distribute their films to television; and that United had violated its contractual obligations by failing to do so.1t The court held,

distributor contracts to market films for an independent producer. LiNDEv, Morio: PICture Agreearents Annotated 569 (1947).

In 1954 United Artists distributed 10 films grossing over \$1 million apice. Variety, Jan. 5,1955, p. 59 . It is the only major distributor whose business is devoted exelusively to distributing for independent producers, but the other majors engage in the practice to some extent. Transcript of Record, pp. 236-37, United Artists Corp. v. Strand Productions, Inc., 216 F.2d 305 (9th Cir. 1954) (hereinafter cited as Transcript). United, in connection with this distribution contract, loaned Nasser $\$ 150,000$ for use in the production of the films. Transcript, p. 201. "Package deals," by which distributors finance independents and distribute the pictures made through such financing, are becoming increasingly popular. See Newsweek, Miarch 7, 1955, p. 75; N.Y. Times, March 27, 1955, pt. 2, § 1, p. 5, col 1.

10. United Artists Corp. v. Strand Productions, Inc, 216 F.2d 305, 309 (9th Cir. 1954).

11. "The parties hereto agree that television may require a new method, manner or system of marketing motion pictures. Accordingly, United Artists agrees with respect to such motion pictures as to which Producer owns the necessary television rights United will market such motion pictures in relation to television in the same manner and under the same method as may be from time to time adopted by other major motion picture distributors and at rates approximately not less favorable to Producer than those from time to time adopted by other comparable television distributing agencies. If and when television shall become a commercial practice and United shall not then acquire the necessary facilities with which to market motion pictures in the television field in a manner favorably comparable to its present-day standards of distribution, then Producer shall be privileged to dispose of its television rights in the motion pictures to any other party." Id. at 307-08.

12. Id. at 307 .

Arthur B. Krim, president of United Artists, testified that the policies of United Artists are patterned after those of the other majors; that to his knowledge no major has distributed to television films originally made for theatre exhibition; that he is in constant cuntact with the top executives of the other majors and has been informed that they have nu intention to distribute their films to television in the immediate future; and that United Artists will follow the others in that respect, although it has made no agreement to do su. Transcript, pp. 206-09.

13. United Artists Corp. v. Strand Productions, Inc., 216 F.2d 305 (9th Cir. 1954).

The referee in bankruptcy filed an order granting Strand the television rights to the films in question and the district court affirmed his order. Transcript, pp. 86-93, 173-84. United Artists appealed to the ninth circuit. Strand cross-appealed the finding that, since distribution to television was not divisible from the remainder of the contract, the television clause was not executory and could not be rejected by the trustee in bankruptcy on that ground. The ninth circuit affirmed the decision of the lower court on that issue. Unitsd Artists Corp. v. Strand Productions, Inc., supra, at 312.

14. The films had a television rental value of at least $\$ 160,000$. Transcript, pp. 90, 182 .

Strand argued that television was a commercial practice and that L'nited's promice to 
however, that the conduct of the majors was the measure of the obligation. It stated that the commercial soundness of following that conduct was not properly in issue ${ }^{15}$ United had not only a right but a duty to follow the pattern of non-distribution the other majors had established. ${ }^{\text {to }}$ The court rejected Strand's argument that, thus construed, the television clause was illegal and unenforceable because it violated the Sherman Act.17 It stated that an agreement is not illegal as in restraint of trade unless it is "between actual competitors."18

The court dismissed the competitive significance of United's "follow-theleaders" clauses too readily. ${ }^{19}$ It is settled law that an agreement need not be "between actual competitors" in order to violate the Sherman Act if its effect is unreasonably to restrain competition. ${ }^{20}$ Strand asked the court to find a conspiracy among the majors to boycott television $;^{21}$ it failed to argue the restraining effects of the clauses absent such a conspiracy. However, Strand was not the only one who had a stake in invalidating the "following" clituses; the public interest in free competition was also involved. ${ }^{22}$ If the effect of the

acquire the facilities necessary to distribute to television, see note 11 supra, carried with it an implied promise to use those facilities. Brief for Appellees, pp. 37-44, United Artists Corp. v. Strand Productions, Inc., 216 F.2d 305 (9th Cir. 1954) (hereinafter cited as Bricf for Appellees). He also argued that there was an implied covenant by United, as by any exclusive licensee distributing on a royalty basis, to use its best efforts to obtain the largest gross returns possible within the limits of sound commercial practice. Id. at 38-40. Sce note 32 infra.

15. United Artists Corp. v. Strand Productions, Inc., 216 F.2d 305, 311 (9th Cir. 1954). See note 16 infra.

16. "United's duties and its privileges [are] co-extensive; that is, if the major producers as a policy are putting certain films simultaneously into theatres and television, United has a right and a duty to do the same with producer's four pictures. ... [U]nless the other major producers are putting a substantial portion of their pictures simultancously or successively into the theatres and television, United has no right to do so." United Artists Corp. v. Strand Productions, Inc., 216 F.2d 305, 311 (9th Cir. 1954).

17. Id. at 311-12.

18. Id. at 311.

19. This note does not contend that the court necessarily erred in failing to find an illegal restraint of trade. It is maintained, however, that the court did err in failing to consider the significance of the effects of the television clauses on the relevant markets.

20. See cases cited note 2 supra. The court cited no authority to sustain its position. United Artists Corp. v. Strand Productions, Inc., 216 F.2d 305, 311 (9th Cir. 1954).

21. Brief for Appellees, pp. 30-32.

Strand had not made the antitrust implications of these clauses an issue before the referee or the district court. He introduced the contention for the first time in his appellate brief. See United Artists Corp. v. Strand Productions, Inc., 216 F.2d 305, 311, 312 n.3 (9th Cir. 1954).

The court could have inferred the existence of a conspiracy among the majors from their joint refusal to distribute feature films to television. See note 43 infra. It then could have found that the following clauses were an "intrinsically" illegal part of that conspiracy. See note 24 infra. However, the evidence in the record was insufficient to compel a finding of conspiracy. See note 43 infra.

22. "Where the interests of individuals or private groups or those who bear special relation to the prohibition of a statute are identical with the public interest in having a 
clauses (as interpreted) ${ }^{23}$ was unreasonably to restrain trade, the clauses were unenforceable and relief should have been granted.-2 The court was not bound

statute enforced, it is not uncommon to permit them to invoke sanctions. This stimulates one set of private interests to combat transgressions by another without resort to governmental enforcement agencies ... [and it puts] back of such statutes a strong and reliable motive for enforcement, which relieves the government of the cast of enforcement." Bruce's Juices, Inc. v. American Can Co., 330 U.S. 743, 751. (1947) (dictum). But ef. Ring v. Authors' League of America, Inc., 186 F.2d 637 (2d Cir. 1951 ).

United's contracts would continue in effect if not invalidated, see note $24 \mathrm{infra}$, so that if they were unreasonable Strand's pecuniary interests would be identical with "the broad public interest in freeing our competitive economy from trade restraints . . . " Loclihart, Violations of the Anti-trust Law's as a Defense in Ciril Actions, 31 Mfmu. Lo Rev. 507, 538 (1947) (quoting from MacGregor v. Westinghouse Elec. \& Mfg. Co., 329 U.S. 394, 400 (1947)). While the first line of private enforcement may properly be treble damage suits, see note 24 infra, treble damage suits are not always adequate. Loelhart, sipro at 570, and TNEC monographs cited therein at 570 n.318; Donovan \& Irvine, Proof of Danages ander the Anti-trust Law, SS U. PA. L. REv. 511, 524-26 (1940); Note, 49 YaLE L.J. 284, 296-99 (1939).

23. The "following" clause in United is ambiguous. See note 11 supra. If two interpretations of a contract are possible, a court should not choose one that will make the contract illegal. 3 CoRBrN, CoNTracts $\$ 546$ (1951). It would have been quite as reasonable to interpret the clause as a promise to distribute if distribution should become profitable. Such an interpretation would have steered the court clear of antitrust dangers. While there was not sufficient evidence in the record to demonstrate conclusively that the clause, as interpreted, would be in unreasonable restraint of trade, it should have been apparent that there was considerable question. It is preferable for a court to interpret a contract in such a way as to avoid danger of conflict with public policy. American Mach. \& Metals, Ine. v. De Bothezat Impeller Co., 180 F.2d 342, 347 (2d Cir. 1950).

24. A buyer cannot defend against a seller's price or damage action on a contract for the sale of goods on the ground that the seller was engaged in an illegal price-fixing conspiracy unless he can also show that the sales contract was "intrinsically" illegal rather than merely "collateral" to another illegal contract or conspiracy. Connolly $v$. Union Sewer Pipe Co., 184 U.S. 540 (1902) ; Continental Wall Paper Co. v. Louis Voight \& Sons Co., 212 U.S. 227 (1909) ; D.R. Wilder MIfg. Co. v. Corn Products Co., 236 U.S. 165 (1915); A.B. Small Co. v. Lamborn \& Co., 267 U.S. 248 (1925). See Loclihart, sipra note 22, at $516-40$.

If the theory of this note is correct the "following" clauses in United are intrinsically illegal. Their illegality is not collateral to some related conspiracy; it results from the clauses' direct effect on non-collusive oligopolistic market behavior. See text at notes 3044 infro. Intrinsic illegality is an imprecise and as-yet undefined concept. See Lyons v. Westinghouse Elec. Corp., 23 U.S.L. WeEr 2505 (2d Cir. March 29, 1955). But extrinsic evidence may be admitted to show intrinsic illegality. Sola Elec. Co. v. Jefferson Elec. Co., 317 U.S. 173 (1942) ; MacGregor v. Westinghouse Elec. \& Mffg. Co., 329 U.S. 402 (1947) ; Edward Katzinger Co., v. Chicago Metallic Mfg. Co., 329 U.S. 394 (1947).

In addition, the Comolly line of cases involved sales contracts that had been fully executed by seller or fully breached by buyer. In United the licensing contracts, as upheld, had several years to run. Actions to invalidate continuing contracts are in the nature of the injunctive relief expressly permitted for any antitrust violation by $\$ 16$ of the Clayton Act, 38 Stat. 737 (1914), 15 U.S.C. $\$ 26$ (1952). Here, "the question is nut whether a party to a contract deserves to be punished ... but it is whether the public deserves to be protected against harm that might result from the execulion of that contract." Gelltorn, Contracts and Public Policy, 35 Colum. L. Rev. 679, 694 (1935) (emphasis added). See Lockhart, supra note 22, at 573. The distinction between enforcing continuing contracts 
by the limitations of counsel's argument. ${ }^{25}$ It should have inquired more fully into the nature of the film industry and the role of the "following" clatuses in the pattern of competition.

The distributive phase of the motion picture industry is oligopolistic in both structure and behavior. Eight major distributors share ninety-five per cent of the business. ${ }^{26}$ In recent years courts frequently have convicted the majors of abusing their power through anti-competitive practices. ${ }^{27}$ Their policies seem consciously geared toward minimizing competition. ${ }^{28}$ This is well illustrated

and denying to buyers the right to renege on completed contracts was explicitly drawn by the court in United Cigar-Whelan Stores Corp. v. H. Weinreich Co., 107 F. Supp. 89 (S.D.N.Y. 1952). The Supreme Court has not expressly distinguished the two instances, but apparently has employed a different rule in cases concerning contracts with executory periods remaining. See Dr. Miles Medical Co. v. Park \& Sons Co., 220 U.S. 373 (1911); Boston Store v. American Graphophone Co., 246 U.S. 8 (1918); Lockhart, supra note 22, at 524 .

Strand probably has the additional remedy of a treble damage suit against United. 38 Stat. 731 (1914), 15 U.S.C. $\$ 15$ (1952). The defense of "unclean hands" is inapplicable to treble damage actions. Kiefer-Stewart Co. v. Joseph E. Seagram \& Sons, Inc., 340 U.S. 211 (1.951) ; Moore v. Mead Serv. Co., 190 F.2d 540 (10th Cir. 1951), reversing 184 F.2d 338 (10th Cir. 1950), cert. denied, 342 U.S. 902 (1952). And the defense of "pari delicto," where plaintiff is an active participant in the illegal scheme of which he complains, now seems of doubtful validity. See Comment, 61 YALE L.J. 1010, 1029 (1952); 48 Nw. U.L. Rev. 619, 622 (1953). But see Eastman Kodak Co. v. Blackmore, 277 Fed. 694 (2d Cir. 1921) ; Bluefield S.S. Co. v. United Fruit Co., 243 Fed. 1 (3d Cir. 1917), error dismissct, 248 U.S. 595 (1919). It seems clear in any event that the defense is ineffective where the plaintiff is a "victim" of the restraint, even though a party to the contract in issue. Ring v. Spina, 148 F.2d 647 (2d Cir. 1945) ; Hartford-Empire Co. v. Glenshaw Glass Co., 47 F. Supp. 711 (W.D. Pa. 1942); National Supply Co. v. Hillman, 57 F. Supp. 4, 7 (W.D. Pa. 1944) (dictum).

25. "In determining what public policy requires, there is no limit whatever to the 'sources' to which the court is permitted to go; and there is no limit to the 'cvidence' that the court may cause to be produced ...." 6 Corbin, Contracrs $\S 1375$ (1951).

Restraints of trade are illegal as against public policy only if they are "unreasonable" restraints; therefore the court would be free to inquire into the market effects which would determine whether a given plan is against public policy. The appellate court can remand to the district court in order to have evidence taken on this point. Cf. Ford Motor Co. v. NLRB, 305 U.S. 364, 373 (1939); Villa v. Van Schaick, 299 U.S. 152, 155 (1936); Dyer v. Commissioner, 211 F.2d 500, 506-07 (2d Cir. 1954).

26. Motion picture distribution is dominated by the eight majors: Paramount, Twentieth Century-Fox, Metro-Goldwyn-Mayer, Warner Bros., RKO (the "Big Five"), Universal, Columbia, and United Artists (the "Little Three"). The first seven produce and distribute films; United is engaged solely in marketing films for independent producers.

In 1954, the eight majors distributed 109 of the 114 films that returned a gross domestic rental of over $\$ 1$ million. They collected $\$ 269$ million of the $\$ 280$ million collected in rentals by companies that distributed at least one film grossing over $\$ 1$ million. Variety, Jan. 5 , 1955, p. 59. Statistics for other years are available in the sources listed in note 28 infra.

27. See, e.g., United States v. Paramount Pictures, Inc., 334 U.S. 131 (1948) ; Interstate Circuit, Inc. v. United States, 306 U.S. 208 (1939); Milgram v. Loew's, Inc., 192 F.2d 579 (3d Cir. 1951); William Goldman Theatres, Inc. v. Loew's, Inc., 150 F.2d 738 (3d Cir. 1945).

28. See Huetrig, Econonic Control of the Motion Pictuhe Industiky (1944); 
by their uniform refusal to distribute feature films to the television industry.90 The exhibitors to whom the major distributors now supply feature films compete with television for the business of the entertainment "market." Apparently the majors considered it better business to restrict feature films to theaters than to compete with each other for the immediate profits to be gained by distributing films to television. ${ }^{30}$

By using "following" clauses in their licensing agreements United and other majors ${ }^{31}$ are able to reconcile their interest in keeping feature films away from television with their fiduciary obligations to independent producers. United is an exclusive licensee distributing Strand's films on a royalty basis: in the absence of the "following" clause the law would impose an implied covenant upon United, requiring it to use its best efforts to secure the largest gross receipts for the licensor. ${ }^{32}$ A best-efforts covenant would not preclude United from following the other majors if that were profitable, but following the majors would not always bring maximum returns to the licensor. The films in United were worth considerably more to movie-starved television networks than they were to theater owners. ${ }^{33}$ Thus, United's interest in keeping films from television conflicted with Strand's interest in maximizing receipts from its property. Except for the "following" clauses United would

Bertrand, The Miomon Picture Industri-A Pattern of Control (TNEC Mlonograph No. 43, 1941) ; Hellmuth, The Motion Picture Indusiry, in The Structure of Assericn:: InDUSTRy 267 (Adams ed. 1950) ; McDonough \& Winslow, The Jiolion Pieture Indusiry: United States v. Oligopoly, 1 Stax. L. Rev. 385 (1949).

29. See testimony of Mr. Arthur Krim, president of United Artists, supra note 12.

30. The movies in United were worth more to television than they were to theater owners. See note 33 infra. Any single major distributor might have made large profits by distributing films to television channels. But the bonanza would have been short-lived, for the other majors probably would have begun selling to television; the television market price would have gone down; and very possibly the theater owners' demand for those and other films would have decreased. See text at notes 39-42 infra.

31. Mr. Krim testified that United Artists has used this type of agreement in the distribution of 75 to 100 films. Transcript, pp. 259-61. See Letter from the Department of Justice to the Yale Law Journal, March 9, 1955, on file in Yale Law Library: "Our experience with [the "following"] clause, while unfortunately too limited to state categorically whether it is in common use, on the other hand, does indicate that its use in the industry is not confined to United Artists and Strand. We have seen similar provisions in contracts of motion picture companies other than United Artists."

32. Mechanical Ice Tray Corp. v. General Motors Corp., 144 F.2d 720, 725 (2d Cir. 1944) ; In re Waterson, Berlin, \& Snyder Co., 48 F.2d 704, 709 (2d Cir. 1931); Pritchard v. MrcLeod, 205 Fed. 24 (9th Cir. 1913). See 3 Corbin, Contracts $\$ 567$ (1951). Ordinarily, a best-efforts covenant will be expressly provided for in a distribution contract. See Lr:az;, Motion Picture Agreensents Annotated 577 (1947). Such a covenant was incorporated into the instant contracts. United Artists Corp. v. Strand Productions, Inc., 216 F.2d 305, 308 (9th Cir. 1954). But the court held that, as to television, it was superseded by the more specific provisions of the clause reprinted in note 11 supra.

33. Each picture had a current minimum value of $\$ \$ 0,000$ for television distribution. Transcript, pp. 90, 182. Apparently this was considerably more than they could earn if marketed exclusively to theater exhibitors; they had little more than a reissue putential remaining. Id. at 252,258 . United introduced testimony that it would be "unsound busi- 
have to use sound business judgment to resolve the conflict. ${ }^{34}$ And if it ignored the interests of its licensor it would be subject to an accounting in court. $^{35}$ By permitting United to complete its obligations by doing as the majors do, the court disregarded a valuable opportunity to spur competition. ${ }^{30}$

The heart of the problem is that in an oligopoly there is an inherent tendency to make cooperative rather than independent business judgments. ${ }^{37} \mathrm{~A}$ few large sellers dominate the market, ${ }^{38}$ and each knows that his policies have a substantial effect upon market conditions and upon the market policies of the others. ${ }^{39}$ All behavior necessarily assumes the character of bargaining,

ness policy" for it to distribute the films to television because theater exhibitors threatened to refuse to exhibit United's films if it did so. Testimony of Arthur Krim, id. at 202-03, 242-45. But there was also testimony that television exhibition may have a negligible effect on a picture's value for theater exhibition. Id. at 303-04.

34. In United the court interpreted the clause so that following the other majors was made a duty as well as a right; United was unable to distribute the films to television cven if it should have desired to do so. Giving United the right to follow the other majors is sufficient to make that result probable; to make the right a duty is to insure it. Under the court's interpretation United has no choice to make.

35. The contract contained a provision by which the producer was privileged to dispose of his television rights to another party if the distributor were found to have failed in his obligation. See note 11 supra. Even without such a provision, a breach of covenant would give rise to an action for damages and might, depending upon its materiality, furnish grounds for rescission or termination. 4 CoRBIN, Contracts $\$ 948$ (1952); 6 Id. $\$ 1253$.

36. Upholding the producer's right to enforce his financial interests is especially important in an industry like the movies, where the bargaining position of a major distributor is superior to that of an independent producer. Independent producers were once unable to obtain either financing or access to the screens of first-run theatres without a major release. See BERTRAND, op. cit. supra note 28, at 53; HUETTIG, op. cit. supra note 28, at 84; Hearings Before the Subconmittee of the Committee on Interstate Commcrce on Scnate Resolution 152, 77th Cong., 1st Sess., 248-65 (1942). While less true after the Paramoumt case, which divested the majors of most of their theatre holdings, it is probable that a major distributor is still able to pressure an independent producer into accepting a clause which would free the distributor from a best-efforts obligation. Thus, intervention by the court should have a positive effect upon competition.

37. See Chamberlin, The Theory of Monopolistic Competition 46-55 (6th ed. 1950); Handler, A Study of the Construction and Enforcensent of the Federal Antitrust Laws 40-45 (TNEC Monograph No. 38, 1941); Feliner, Collusion and lis Limits Under Oligopoly, 40 Am. Econ. Rev. 54 (Supp. I 1950); Fly, Observations on the Anti-Trust Laws, Economic Theory and the Sugar Institute Decisions, 45 YALE L.J. 1339 (1936), 46 YALE L.J. 228 (1937).

38. Wilcox, Competition and Monopoly in American Industry 5 (TNEC Monograph No. 21, 1940). An equally important characteristic of oligopolistic markets is that entry by newcomers is difficult and oligopolists generally attempt to keep it that way. Rostow, The New Sherman Act: A Positive Instrument of Progress, 14 U. Cur. L. Riv. 567,576 (1947).

39. "Such sellers are conscious in every phase of their market policy of the fact that what they do will have an effect upon the market as a whole. . . Such intercsts and attitudes inhibit price competition more effectively than collusion or conspiracy, and they color every aspect of price and production policy." Rostow, supra note 38, at 576; see CiranuERLIN, op. cit. supra note 37, at 48; WiLcox, op. cit. supra note 38, at 5; Fellner, supra note 37, at 54; Rostow, Monopoly Under the Sherman Act: Pozver or Purpose?, 43 ILL. L. Ruv. 745, 782-83 (1949). 
and every act or failure to act is an invitation to follow. 40 Competition between oligopolists is not profitable. Each is aware that he is probably incapable of increasing his share of the market; he is primarily interested in maintaining his share as it stands. ${ }^{41}$ The almost inevitable result is gentlemanly cooperation, which may be attained without overt agreement or even direct contact. ${ }^{42}$ The present status of the law appears to be that cooperation is not illegal unless it is found to rest upon an agreement. ${ }^{13}$ But illegal or not, its effect is to restrain competition. ${ }^{4}$

40. "For, even without direct contacts, the moves of each participant will show his reaction to what the others have been doing, and, at the same time, whatever a participant does will help test the reactions of the others. Hence, the moves of the various participants assume the character of offers and of replies to offers. Even in the absence of direct negotiations we are faced with bargaining in the broad sense, as long as each participant is appreciably affected by the individual moves of the other participants." Fellner, supro note 37 , at 54.

Cf. FTC v. Cement Institute, 333 U.S. 683, 716 n.17 (1948) ; United States v. Afasonite Corp., 316 U.S. 265, 275 (1942) ; Interstate Circuit, Inc. v. United States, 306 U.S. 208, 226-27 (1939). See Note, 64 Y ALE L.J. 581, 585 (1955).

41. "Their output is a significant share of total supply. If they produce more, it an be sold only at a sacrifice of price. If they alter their policy as to price or output, they know that their rivals will follow suit. A price cut therefore can rarely change any seller's share of the market. . . Fear of spoiling the market is thercfore a deep-seated and characteristic quality of many markets dominated by a few large firms." Rostow, supra note 38, at 577. See Burns, The Dectine of Cosrpentrion 40-42 (1936).

Not only does cooperation enable an industry to avoid ruinous competition, but in addition output and prices may be regulated so as to obtain maximum profits, and marliets may be shared so as to effect monopolies in limited areas. See Crusrberun, op. cii. supro note 37, at 48-55; note 10 stipra. For when oligopolists act as one, they act as monopolists. Every participant "has an interest in reaching an 'agreement,' even at the expense of concessions." Fellner, supra note 37, at 55.

42. See notes 39 and 40 supra.

43. As to "conspiracies," "the Sherman Act requires some sort of joint conduct or concert of action as a necessary element of violation. ... The concern of the section scems to be with 'restraint of trade,' but Congress did not condemn it directly." Rahl, Conspiracy and the Anti-trust Lazes, 44 ILI. L. REv. 743, 744 (1950). Of course, the agreement need not be explicit; it may be inferred from circumstantial evidence showing uniformity of policy and practice, past proclivity for wrongful conduct, and action in apparent contradiction to self-interest. Milgram v. Loew's, Inc., 192 F.2d 579, 583-84 (3d Cir. 1951) ; see Interstate Circuit, Inc. v. United States, 306 U.S. 208, 226-27 (1939) ; United States v. Mrasonite Corp., 316 U.S. 265, 275 (1942) ; United States v. Paramount Pictures, Inc., 334 U.S. 131, 142 (1948). See Report of the Attorney General's Natjonal Cosaritree to Study THE ANTI-TRUST LAws 37 (1955). However, evidence of uniform conduct standing alone does not compel such an inference. Id. at 38-39; Theatre Enterprises, Inc v. Paramount Film Distributing Corp., 346 U.S. 537, 540-41 (1954). Cf. Milgram v. Locv's, Ine, supro at 583; Dipson Theatres, Inc. v. Buffalo Theatres, Inc., 190 F.2d 951, 957 (2d Cir. 1951). But of. Rostow, supra note 39, at 784. Economic analysis of market structure may suggest important leads to relevant evidence; evidence of economic interdependence is always relevant to prove the cooperative use of market power. But the law does not assume that actual market behavior corresponds to the pattern that would theoretically be espected in a market of a given structure.

44. "Harm to the public interest would seem to lie in the result, not in the formalities." 
Attacking oligopolistic cooperation through the ancillary agreements used to sustain it can become an effective means of enforcing the antitrust laws. ${ }^{40}$ Oligopolists may be able to cooperate without "agreeing," but they cannot carry on their businesses without entering into selling or licensing contracts. If the contracts contain ancillary provisions which promote uniform practice, they should be subjected to the Sherman Act's tests of legality and struck down unless they are found to be "reasonable." 46 Permitting private litigants to attack such provisions may compel the oligopolist to formulate his policies on the basis of sound and independent business judgment.

Rahl, supra note 43, at 745; see Milgram v. Loew's, Inc., 192 F.2d 579, 583 (3d Cir. 1951) (dictum) ; Bond Crown \& Cork Co. v. FTC, 176 F.2d 974, 979 (4th Cir. 1949) (dictum). See FTC Notice to the Staff: In Re: Commission Policy Tozuard Geographic Pricing Practices (October 12, 1948); Report of the AtroRney General's National CoumutTEe to Study the ANtitrust Laws 38 (1955); HaNdLer, op. cit. supros note 37, at 41, 42; Rostow, supra note 38, at 576-77; Rostow, supra note 39, at 784, 790.

45. The policy behind the Sherman Act is promoted by permitting and encouraging private litigants to bring civil actions attacking ancillary covenants which unreasonably restrain trade. See Bruce's Juices, Inc. v. American Can Co., 330 U.S. 743, 751 (1947) (dictum), quoted in note 22 supra. The private litigant has an imposing arsenal of weapons at his disposal: he may sue for treble damages for injuries sustained because of the illegal contracts; sue to enjoin the continued enforcement of the contract under $\$ 16$ of the Clayton Act; set up the contract's illegality as a defense to actions brought by the other party; and sue to rescind the contracts. See notes 24,35 supra. These suits should be encouraged. They serve the double purpose of permitting illegal contracts to be avoided and of discouraging parties from making them. Their nuisance value could prove to be especially important. Permitting these suits may, in some cases, work a hardship upon one party and come as a windfall to the other; but that is an incident to entering contracts that are opposed to public policy. Certainly, however, if the illegal provision is severable from the remainder of the contract, only the illegal portion need be condemned. Restatement, Contracts $\S 518$ (1932).

46. The legality of an ancillary covenant will vary from industry to industry; its cffect upon competition will change with the behavioristic and structural context of the market in which it is used. See Appalachian Coals, Inc. v. United States, 288 U.S. 344, 360-61 (1933) ; Board of Trade of Chicago v. United States, 246 U.S. 231, 238 (1918) ; Standard Oil Co. of California v. United States, 337 U.S. 293, 309 (1949). See Report of THE Atronney General's National Committee to Study the Antitrust laws 39 (1955). Thus "open competition" plans conducted by trade associations have been condemned under the Sherman Act when, in view of the structure and behavior of the industries involved, they tended to facilitate cooperation. E.g., compare Sugar Institute, Inc. v. United States, 297 U.S. 553 (1936), with Maple Flooring Manufacturers Ass'n v. United States, 268 U.S. 563 (1925). See Stocking, The Rule of Reason, Workable Competition, and the Legality of Trade Association Activities, 21 U. Crr. L. Rev. 527 (1954).

Ancillary covenants requiring a distributor to match the performance of competing distributors would not, of course, be unlawful under all circumstances. In each case the court must balance the businessman's need for the protection such a standard affords him with its effect upon competition. See note 3 supra. In a competitive industry the use of such a standard may have no significant effect upon competition. HANDLER, op. cit. supra note 37, at 40; Fellner, supra note 37, at 55. And its use may even increase competition if it permits smaller firms to take business away from an established rival by promising to do as good a job as the established firm has done. But it is not vital to the protection of either party, and in an oligopoly it is a powerful inducement to abandon competition. 